\title{
Lider polityczny $w$ totalitarnym i demokratycznym systemie politycznym. Pozorna opozycja?
}

$\mathrm{P}$ ODKREŚLANIE ZNACZENIA JEDNOSTKI W DZIEJACH nie jest zagadnieniem nowym, podobnie jak przypisywanie przełomowej roli w historii działaniu przywódców. Nie ulega także wątpliwości, iż kwestia znaczenia jednostki w totalitarnym i demokratycznym systemie politycznym wiąże się z koncepcją przywództwa charyzmatycznego, wprowadzoną do nauk społeczno-politycznych przez Maxa Webera, który wyróżnił trzy typy idealne prawomocnego panowania: tradycyjne, legalne oraz charyzmatyczne, podkreślając, iż w praktyce mamy najczęściej do czynienia z typami mieszanymi ${ }^{1}$. W koncepcji niemieckiego socjologa charyzmatyczny mechanizm legitymizacji ${ }^{2}$ opiera się na wysoce pozytywnym wartościowaniu osobistych cech przywódcy. Rządzeni

${ }^{1}$ W. Stankiewicz, Cechy wspótczesnego przywództwa politycznego, [w:] Dokąd zmierza Europa: przywództwo, idee, wartości, red. H. Tamborska, J. S. Wojciechowski, Pułtusk 2007, s. 231-232.

${ }_{2}$ Źródłosłów terminu legitymizacja (ang. - legitimacy, legitimisation, legitimisation of authority, legitimisation of the power; franc. - legitime; ros. - legitimnost) pochodzi bądź od łacińskiego słowa legitimus, czyli zgodny z prawem (lex - prawo), bądź od słowa wywodzącego się z łaciny średniowiecznej - legitimo. Legitymizacja to proces wiodący do legitymacji (prawomocności) - pewnego ogólnie akceptowanego stanu systemu politycznego, ładu społecznego. W. Sokół, Legitymizacja systemów politycznych, Lublin 1997, s. 15-16. Legitymizacja (legitymizacja polityczna) bywa również traktowana jako „skomplikowany, wielowymiarowy i wielowątkowy proces wytwarzania akceptacji dla systemu politycznego i podmiotów władzy politycznej”. L. Sobkowiak, Legitymizacja polityczna, [w:] Studia z teorii polityki, t. 2, red. A. W. Jabłoński, L. Sobkowiak, Wrocław 1998, s. 156. „Właściwym celem legitymizacji jest skuteczność i przetrwanie rzeczywistości społecznej rozpatrywanej na płaszczyźnie obiektywnej i subiektywnej, zachowanie i gwarancja stabilności społecznie wytwarzanych definicji rzeczywistości społecznej, jej struktur i zachodzących w niej procesów społecznych. Legitymizacja stanowi podstawę integracji społeczno-kulturowej i służy zachowaniu ładu społecznego. Zgodnie ze swoim łacińskim znaczeniem jest traktowana jako zgodność z prawem, prawość, prawowitość, należytość”. W. Świątkiewicz, Wprowadzenie. Legitymizacja: zagadnienia podstawowe, [w:] Świat społeczny i jego legitymizacje, red. W. Świątkiewicz, Katowice 1993, s. 7. 
postrzegają takiego lidera, jako osobę o wyjątkowych kompetencjach i kwalifikacjach ujawnianych podczas pełnienia istotnych dla społeczeństwa ról, np. męża opatrznościowego, bohatera, zwycięskiego wodza. Osoba taka ma zwykle (lub otoczenie przypisuje jej) wybitne zdolności emocjonalne i/lub intelektualne wpływania na otoczenie społeczne i wytwarzania dla siebie sprzężenia zwrotnego. Poddani darzą takiego przywódcę głębokim szacunkiem, uwielbieniem, oddaniem, zaufaniem i gotowi są do daleko idących poświęceń w realizacji jego decyzji ${ }^{3}$. „Charyzma uchodzi więc za najatrakcyjniejszy model przywództwa. Zapewnia ludziom ambitnym poczucie osobistego uznania, wpływu i sukcesu opartego na osobistych zaletach, zasługach i osiągnięciach. Tylko charyzmatyk może pozyskać «żarliwych» zwolenników, wiernych wręcz fanatycznych «wyznawców», w swym przekonaniu będąc osobą kluczową"4. Ta swoista teoria przywództwa stworzona przez współczesny paradygmat naukowy zakłada, że przywódcą jest tylko taka jednostka, która „wyróżnia się osobistym lub instytucjonalnym autorytetem i zajmuje wysoką pozycję społeczną, dzięki czemu może narzucać innym swój punkt widzenia i wywoływać w nich działania dla urzeczywistnienia własnych celów. A zatem przywódca jest człowiekiem mądrym, a co za tym idzie rozumiejącym i stosującym definicję mądrości Immanuela Kanta, zgodnie z którą mądrość jest zręcznością człowieka we wpływaniu na drugich, by użyć ich do własnych celów i umiejętnością łączenia tych celów dla własnej, trwałej korzyści” 5 .

Jednostka w polityce zawsze stanowiła istotny element sprawczy. Co więcej, była i jest ważnym czynnikiem poparcia mobilizacyjnego ${ }^{6}$. Otwartym pozostaje jedynie pytanie, jakie jest znaczenie jednostki w totalitarnym systemie sprawowania władzy, a jakie w systemie demokratycznym, i czy istota przywództwa w tych systemach faktycznie

\footnotetext{
${ }^{3}$ L. Sobkowiak, Legitymizacja..., op. cit., s. 151.

${ }^{4}$ M. Karwat, Charyzma i pseudocharyzma, „Studia Politologiczne” 2001, vol. 5, s. 126.

${ }^{5}$ A. Karpiński, Wiek XXI będzie wiekiem przywódców albo nie będzie go wcale, [w:] Dokqqd..., op. cit., s. 213.

6 Koncepcja poparcia mobilizacyjnego została zaprezentowana przez Davida Beethama. Zgodnie z jego teorią we współczesnych systemach politycznych wyróżnić możemy dwa rodzaje poparcia: w ramach procesu wyborczego oraz właśnie poparcie typu mobilizacyjnego. Typ mobilizacyjny zakłada, że poparcie wyrażone jest przez długotrwałą, masową aktywność obywateli i współpracę z rządem. I to właśnie permanentna mobilizacja tworzy szczególne zapotrzebowanie na przywództwo charyzmatycznych kwalifikacji. D. Beetham, Legitymizacja władzy, [w:] Wtadza i spoteczeństwo, red. J. Szczupczyński, Warszawa 1995, s. 299.
} 
nie sprowadza się do jednego, wspólnego celu - legitymizacji systemu i podstawowych dla niego wartości?

\section{KULT JEDNOSTKI W SYSTEMIE TOTALITARNYM}

SŁUSZNE WYDAJE SIĘ TWIERDZENIE, że rozwój totalitarnego systemu sprawowania władzy nie musi przyczynić się do powstania wynaturzonego przywództwa charyzmatycznego - kultu jednostki, tendencja ta jest jednak powszechna7. Nawet intuicyjnie władza silnej, samodzielnej jednostki jest identyfikowana właśnie z systemem niedemokratycznym (autorytarnym lub totalitarnym). Już Friedrich W. Nietzsche w swych dziełach, doceniając rolę irracjonalnej, nieświadomej strony natury ludzkiej, dowodzil, że główną lekcją, którą należy wyciągnąć z historii jest to, iż w wyjątkowych sytuacjach mąż opatrznościowy używa swej woli, by wznieść się ponad poziom stada zwykłych ludzi ${ }^{8}$. Potwierdzeniem powyższej tezy, dotyczącej charyzmatycznej, nietuzinkowej osobowości przywódcy politycznego, stał się wiek XX. Całe minione stulecie i wydarzenia, które miały w nim miejsce w sposób jednoznaczny dowiodły nie tyle prawdziwości tych słów, ile tego, że opacznie zrozumiana lub celowo wynaturzona idea może przyczynić się do niespotykanego nigdy wcześniej dogmatyzmu i okrucieństwa. Planowego i konsekwentnego działania w imię źle pojętej woli jednostki. To właśnie dwa dwudziestowieczne totalitaryzmy (faszyzm i komunizm), propagujące ducha wspólnoty i kolektywizmu do granic absurdu doprowadziły kult jednostki, wodza i przewodnika mas.

W totalitaryzmie lider polityczny, wódz stał się człowiekiem opatrznościowym, wybranym do zagwarantowania ludziom bezpieczeństwa i spokojnego życia. Tak więc, im bardziej sytuacja społeczna stawała się katastrofalna, im większy był stan zanegowania dotychczasowych, tradycyjnych wartości, norm i struktur, tym mocniej poszukiwano wodza, tym gwałtowniej i z większym oddaniem powierzano mu swoje umysły ${ }^{9}$. Owo podporządkowanie wraz ze swoistą religią władzy były (czy też są) efektem pracy ogromnych aparatów propagandowych wykorzystujących najnowocześniejsze sposoby wywierania wpływu w skali masowej ${ }^{10}$.

${ }^{7}$ J. Linz, Totalitaryzm i autorytaryzm, [w:] Władza..., op. cit., s. 309.

${ }^{8}$ R. Eatwel, Faszyzm. Historia, Poznań 1999, s. 48.

${ }^{9}$ Ibidem.

${ }^{10}$ P. Pawełczyk, Legitymizacja totalitarnego systemu sprawowania władzy, [w:] Totalitaryzm. Wybrane problemy teorii i praktyki, red. T. Wallas, Poznań 2003, s. 95. 
Cechą charakterystyczną współczesnych nam systemów totalitarnych jest łamanie i instrumentalne traktowanie norm moralnych. Proces ten objawia się poprzez propagandę, która w swym oddziaływaniu posługuje się stereotypami, aby wpływać na postawy, poglądy i zachowanie sterowanych, ale także przez pokrętną ideologię, którą Hannah Arendt określiła jako zorganizowane kłamstwo (umysłowe i moralne wywłaszczenie człowieka) ${ }^{11}$. Posłuch i legitymizację, próbuje się również osiągnąć poprzez nieustanne oddziaływanie na emocje, wywoływanie poczucia ciągłej mobilizacji i wrzenia rewolucyjnego. Istotnym elementem pozyskiwania społecznej akceptacji jest teatralność widowisk i rytuałów, stanowiących wręcz codzienność systemów totalitarnych (quasi-totalitarnych). Jednak tym, co szczególnie istotne dla uprawomocnienia systemów niedemokratycznych jest kult władzy i przywódców, których traktuje się nieraz z iście boską czcią ${ }^{12}$. Wódz w systemie totalitarnym nie tylko był (jest) uosobieniem władzy, państwa i obowiązującej ideologii, ale także (a może przede wszystkim) jedynym gwarantem stabilności, bezpieczeństwa i niezmienności istniejącego porządku. Tym, który „zdejmował” z ludzi ciążący im nieszczęsny dar wolności i odpowiedzialności za swój los.

ZJAWISKO PERSONALIZACJI POLITYKI W DEMOKRATYCZNYM SYSTEMIE POLITYCZNYM

WE wSPÓ£CZESNYM, demokratycznym świecie tradycyjne i charyzmatyczne przywództwo zostało zastąpione przez legalno-racjonalny system panowania oparty na prawie. W takich układach jednostka aspirująca do politycznego przywództwa musi pokonać pewne bariery instytucjonalne i spełnić określone warunki, by wejść w skład elity władzy ${ }^{13}$. Lecz czy oznacza to, że współczesną politykę da się zrozumieć bez uwzględnienia roli tych nielicznych, którzy stoją na czele wielkich zespołów ludzkich i podejmują szczególnie doniosłe decyzje, słowem bez przywódców ${ }^{14}$ ?

Charakterystyczną cechą współczesnych instytucji demokratycznych takich, jak wybory powszechne, stało się ich „zmarketingowanie” i „mediatyzacja”. Zjawiska te objawiają się ciągłym wzrostem znaczenia środków społecznego przekazu oraz wyspecjalizowanych agencji reklamowych, zatrudniających osoby odpowiedzialne za kreowanie

${ }^{11}$ Szerzej: H. Arendt, Korzenie totalitaryzmu, Warszawa 2008.

${ }^{12}$ P. Pawełczyk, Legitymizacja..., op. cit., s. 90-93.

${ }^{13}$ J. Potulski, Socjologia polityki, Gdańsk 2007, s. 95.

${ }^{14}$ J. J. Wiatr, Europa pokomunistyczna. Przemiany państwa i spoleczeństwa po 1989 roku, Warszawa 2006, s. 272. 
wizerunków polityków i polityki. To z kolei przyczyniło się do ewolucji współczesnego systemu politycznego, w którym zdaniem wielu autorów, coraz częściej występuje zjawisko personalizacji polityki ${ }^{15}$. Choć w zasadzie głosuje się na partie polityczne, a nie na poszczególnych kandydatów, to jednak ich wpływ na sukces wyborczy jest niepodważalny. Przywódca polityczny jest odpowiedzialny za wynik wyborczy swojej formacji i, aby spełniać ciążącą na nim odpowiedzialność, musi cały czas zaspokajać funkcjonujące w stronnictwie frakcje oraz pozyskiwać nowe grupy zwolenników. Tym samym nieustannie dba o zachowanie integralności partii i jej należyte działanie. Maciej Hartliński scharakteryzował to zjawisko w następujący sposób: „Obecnie $\mathrm{w}$ wielu partiach realizowany jest model oparcia identyfikacji partii na przywódcy politycznym. Prowadzenie kampanii wyborczej, skupiającej uwagę głównie na przywódcy pozwala na elastyczność. Łatwiej jest modyfikować zachowanie jednostki niż charakter całej organizacji. Wytworzony obraz polityka generowany jest w celu zaprezentowania jego osoby jako idealnego kandydata, posiadającego idealną osobowość odpowiadającą oczekiwaniom wyborców. Dzięki temu - pisał M. Hartliński - pozytywny wizerunek zostaje przeniesiony na partię, dając oczywiste korzyści. Skutkiem takich okoliczności staje się sytuacja, w której to jednostka zapewnia prestiż całej grupie, stając się istotnym ogniwem w jej funkcjonowaniu"16.

We współczesnym systemie politycznym (dodajmy demokratycznym) mamy więc do czynienia z personalizacją polityki. Grażyna Ulicka stwierdziła, że zjawisko to polega na „utożsamianiu liderów politycznych z reprezentowanymi przez nich partiami, traktowaniu przywódców politycznych: prezydentów, premierów, jako symboli państwa lub narodu"17. W jej opinii personalizacja została spowodowana przez rozwój środków masowego przekazu oraz rozwój administracji i biurokracji, które są odpowiedzialne za zwiększenie stopnia sformalizowania i anonimowości we współczesnych społeczeństwach. Jednocze-

${ }^{15}$ Szerzej: M. Mazur, Marketing polityczny. Wyczerpujacy przegląd technik i metod stosowanych $w$ kampanii wyborczej, Warszawa 2002; A. Stępińska, Marketingowe strategie wyborcze. Wybory prezydenckie w Polsce 1990-200o, Poznań 2000; B. Dobek-Ostrowska, Media masowe i aktorzy polityczni $w$ świetle studium nad komunikowaniem politycznym, Wrocław 2004.

${ }^{16}$ M. Hartliński, Partia polityczna jako miejsce kreowania przywództwa politycznego, [w:] Czy upadek demokracji? Idee i wartości, red. A. Stelmach, Poznań 2007, s. 89 .

${ }_{17}$ G. Ulicka, Demokracje zachodnie. Zasady, wartości, wizje, Warszawa 1992, S. 122. 
śnie zjawiska te - zdaniem G. Ulickiej - rodzą potrzebę odwołania się do osób symbolizujących autorytet i porządek oraz do jednostek, które przejęłyby na siebie odpowiedzialność, a przede wszystkim stworzyły poczucie bezpieczeństwa i bliskości ${ }^{18}$. Proces ten jest szczególnie widoczny we współczesnych kampaniach wyborczych, charakteryzujących się znacznym poziomem personalizacji. Osobowość lidera często zastępuje argumenty programowo-ideologiczne lub odsuwa je na plan dalszy i staje się koronnym argumentem przyciągającym nowych wyborców ${ }^{19}$. Niezależnie od systemu wyborczego dominować zaczęły strategie indywidualne ${ }^{20}$. Dzięki nowoczesnym środkom masowego komunikowania liderzy polityczni bezpośrednio mogą zwrócić się do elektoratu, a wyborcy częściej oceniają realizację działań politycznych przez pryzmat jednostki - znanych osobowości polityki niż „bezimiennej" organizacji partyjnej.

Jednym z pierwszych obserwatorów wspomnianego zjawiska personalizacji był Martin P. Wattenberg, który analizując wybory prezydenckie w Stanach Zjednoczonych Ameryki w latach 80. XX w., obwieścił rozpoczęcie nowej ery w polityce. W jego opinii ten nowy etap można określił mianem polityki skoncentrowanej na kandydacie (candidate centered politics), którą z kolei Bruce I. Newman nazwał „wiekiem fabrykowanych wizerunków” ${ }^{21}$. Stanowisko to było tożsame z koncepcją Anthony Mughana, który stwierdził, iż przywódca i kandydat $\mathrm{w}$ systemie amerykańskim znajduje się na pierwszym planie, partia zaś jest w tle. Dzieje się tak, gdyż prezydent jest jednoosobową egzekutywą, a jego prestiż i znaczenie podnoszą bezpośrednie wybo$\mathrm{ry}^{22}$. Co więcej, A. Mughan zauważył, że problem personalizacji sceny politycznej jest także obecny w systemie parlamentarnym. Badacz ten pisał wręcz o implementacji wzorców amerykańskich i prezydencjalizacji parlamentarnych kampanii wyborczych. Jego zdaniem centralną pozycję w kampanii wyborczej zajęli poszczególni kandydaci. Do podobnego wniosku doszła Marzena Cichosz analizując image liderów politycznych. „Obecnie dzięki promocji lidera znajduje się «nabyw-

${ }^{18}$ Ibidem.

${ }^{19}$ R. Wiszniowski, Marketing wyborczy. Studium kampanii wyborczych $w$ systemach prezydenckich i semiprezydenckich (Finlandia, Francja, Polska, Stany Zjednoczone), Warszawa-Wrocław 2000, s. 72.

${ }^{20}$ Ibidem, s. 56-61.

${ }^{21}$ W. Cwalina, A. Falkowski, Marketing polityczny - perspektywa psychologiczna, Gdańsk 2005, s. 148-149.

${ }_{22}$ A. Mughan, Media and the Presidentialization of Parliamentary Elections, New York 2000, s. 6-7. 
ców» nawet niepopularnych decyzji politycznych, zmienia się pozycję formacji na rynku politycznym, wyciąga z niebytu «polityczną drobnicę», przyciąga zwolenników. Coraz mniej istotne - pisała M. Cichosz - stają się rozbudowane struktury partyjne i rzesza członków formacji zaś tym, co decydująco wpływa na pozycję partii na scenie politycznej, jest obecność lub brak «odpowiedniego» przywódcy - osoby, która będzie potrafiła oddziaływać na masy"23. Innymi słowy, będzie posiadała odpowiedni wizerunek, akceptowany przez szerokie grono zwolenników, obserwatorów politycznej gry i rywalizacji.

\section{KONKLUZJA}

KONTROWERSJE dotyczące roli jednostki w życiu społecznym mają swoje odbicie także w naukach społecznych. Z jednej strony bowiem podkreśla się, że każdy z nas jest małym oczkiem w ogromnej sieci form strukturalnych, z których składa się społeczeństwo ludzkie. Ponieważ każdy człowiek jest umieszczony w układzie struktur społecznych, to ludzkie myśli, postrzeżenia, uczucia, działania oraz interakcję są mocno ograniczone. A zatem to struktura społeczna i kultura determinują nasze zachowania i zmuszają nas do robienia tego, czego same chcą ${ }^{24}$. Z drugiej zaś - we współczesnym rozwoju humanistyki nastąpił odwrót od statycznych modeli systemowych, w których zwracano uwagę na dynamiczny, procesowy charakter życia społecznego pozostającego w nieustannym toku „stawania się”25. Obecnie zakłada się, że świat społeczny to nie trwały i niezmienny stan, lecz raczej nieustanny dynamiczny proces. Jako czynnik sprawczy tego procesu wskazuje się podmioty społeczne, w tym jednostki i ich działania. W tle każdego stanu społecznego (jak i ustroju politycznego: totalitarnego lub demokratycznego) są jacyś ludzie, jakieś zbiorowości, grupy, ruchy społeczne, partie polityczne, stowarzyszenia, których aktywność ten stan spowodowała i konstytuuje. Najpierw była jednostka, a w zasadzie jej wynaturzony kult w systemach niedemokratycznych, które z perspektywy dzisiejszej nauki o polityce można określić jako: monarchie, oligarchie, systemy absolutystyczne, autokracje i totalitaryzmy; następnie pojawiło się zjawisko personalizacji polityki. Jak pisał Piotr Pawełczyk: „Osobowość charyzmatyczna jako źródło władzy była niezbędna od początku kształtowania się dychotomicznych pozycji nad- i podrzędności. Kie-

${ }^{23}$ M. Cichosz, Wizerunek lidera politycznego, [w:] Marketing polityczny a procesy artykulacyjne: przypadek III Rzeczypospolitej, red. M. Jeziński, Toruń 2004, s. 78.

${ }^{24}$ J. H. Turner, Socjologia, Poznań 1998, s. 66-67.

${ }^{25}$ J. Potulski, Socjologia..., op. cit., s. 167. 
dyś oznaczała siłę fizyczną, później przymioty intelektualne i moralne, potem także oratorskie, aby wreszcie zostać sprowadzoną do fotogeniczności oraz umiejętności nieskrępowanego zachowania przed kamerami i mikrofonami” ${ }^{26}$. Nastąpiła więc amerykanizacja polityki, którą Ziemowit J. Pietraś opisał w następujący sposób: „Amerykańska wideopolityka szybko upowszechniła się w innych państwach zachodnich. (...) Amerykanizacja procesów wyborczych polega na: uzyskaniu dominującej roli przez środki przekazu telewizyjnego, personalizacji polityki i większej roli wizerunków medialnych w stosunku do klasycznej prezentacji programów wyborczych, co wiąże się ze spadkiem znaczenia struktur partyjnych i przynależności kandydatów do określonej partii”"

Niewątpliwie w praktyce politycznej wyjątkową rolę pełnią jako podmioty: jednostka, naród i państwo. One kształtują w ważnym stopniu określoną rzeczywistość społeczno-polityczną, przeobrażają ją w kierunku zgodnym z własnymi interesami i potrzebami, wpływają na zachowanie i położenie innych instytucji politycznych, jak np. parlamentu, rządu, partii politycznych, mediów, organizacji międzynarodowych, ruchów politycznych. $\mathrm{Z}$ uwagi na fakt, że dominującym motywem życia w społeczeństwie nowoczesnym stał się indywidualizm upowszechniła się koncepcja człowieka jako istoty, która staje się osobą, gdyż bierze odpowiedzialność za siebie i za los większości, której jest częścią ${ }^{28}$, a to z kolei przyczyniło się do ponownej restauracji znaczenia lidera politycznego we współczesnym systemie demokratycznym.

Piotr Pawełczyk w książce Socjotechniczne aspekty gry politycznej opisując teoretyczne konsekwencje stosowania analogii polityki do gry doszedł do przekonania, iż oddziaływania socjotechniczne skupione na przekazywaniu naczelnych wartości systemu i integrowaniu wokół nich społeczeństwa są cechą charakterystyczną zarówno demokracji skonsolidowanych oraz, co może wydawać się paradoksalne, trwałych systemów totalitarnych. Autor ten stwierdził, iż nie oznacza to, co prawda, że system demokracji skonsolidowanej i system totalitarny są do siebie w sensie wymiernych efektów podobne, jednak nie wartościując ich np. poprzez ocenę respektowania praw człowieka czy

${ }^{26}$ P. Pawełczyk, Propaganda demokracji masowej, „Przegląd Politologiczny” 2003, nr 1, s. 107.

${ }^{27}$ Z. J. Pietraś, Decydowanie polityczne, Warszawa-Kraków 2000, s. 444.

${ }^{28}$ K. Obuchowski, Rewolucja podmiotu i nowy indywidualizm, [w:] Humanistyka przetomu wieków, red. J. Kozielecki, Warszawa 1999, s. 131. 
zakresu wolności, dostrzec można ich znaczne zbliżenie, uwzględniając choćby sposób prezentowania w tych systemach polityki ${ }^{29}$. Stwierdzenie to jest szczególnie interesujące, biorąc pod uwagę prowadzone tu rozważania. Co prawda, P. Pawełczyk dokonał powyższego porównania, odnosząc je całościowo do polityki jako spektaklu politycznego, jednak trudno nie zauważyć, że może ono być zastosowane także w odniesieniu do jednostki - przywódcy politycznego, zarówno w totalitarnym, jak i demokratycznym systemie politycznym. Nadal bowiem lider polityczny stanowi istotne ogniwo w procesie politycznym i decyzyjnym. W systemie totalitarnym uosabia przede wszystkim władzę i obowiązującą ideologię, w demokracji zaś jest punktem odniesienia dla działań politycznych podejmowanych przez rozbudowane struktury partyjne i biurokratyczne.

Jesteśmy świadkami niesamowitej przemiany. Po pierwsze, na obecnym etapie rozwoju cywilizacyjnego każda jednostka ludzka stała się większą niż kiedykolwiek wcześniej wartością autoteliczną. Szczególnego znaczenia nabrała godność istoty ludzkiej. Po drugie, nastąpiła niezwykła rewolucja w pojmowaniu roli i znaczenia jednostki jako siły sprawczej w polityce. Oto na naszych oczach zdeformowany, okaleczony kult jednostki został zastąpiony (a może jedynie przysłonięty) supremacją jednostki w polityce, choć dokonała się ona pod wpływem szeroko rozumianej kreacji wizerunku, rozwoju środków masowego przekazu i marketingu politycznego. Pozostaje jedynie żywić nadzieję, że pragnienia, lęki, namiętności i rozum jednostki skłonią ją raczej ku dobru niż złu ${ }^{30}$; władzy większości, która jest zawodna, niż panowania jednostki, które zawsze prowadzi do tyranii. Musimy bowiem pamiętać, iż istnieją dwie sprzeczne namiętności, które „zżerają” współczesnych ludzi: potrzeba by ktoś prowadził ich za rękę i pragnienie wolności. Stąd pomysł by próbować pogodzić obie, marząc o jednej, opiekuńczej i wszechwładnej władzy, którą wybieraliby wszyscy obywatele $^{31}$, słowem o idealnym przywódcy politycznym, modelu niemożliwym do osiągnięcia w wielopoziomowej i wielowymiarowej strukturze, jaką jest społeczeństwo. I choć powyższa opinia może wydawać się przesadzona, trudno nie odnieść wrażenia, iż współczesny trend związany z personalizacją dyskursu politycznego coraz częściej upo-

${ }^{29}$ P. Pawełczyk, Socjotechniczne aspekty gry politycznej, Poznań 2007, s. 69-71.

${ }^{30}$ E. Fromm, Ucieczka od wolności, Warszawa 2001, s. 18.

${ }^{31}$ A. Rzegocki, Czy demokracja może być totalitarna, [w:] Totalitaryzm a zachowania tradycyjne, red. M. Kuniński, Kraków, s. 215. 
dabnia się do wynaturzonego przywództwa, teraz już pseudo-charyzmatycznego.

\section{SUMMARY}

IN TRADITIONAL AUTHORITY, the legitimacy of the authority comes from tradition, in charismatic authority from the personality and individual's leadership qualities, and in rational-legal authority from powers that are bureaucraticly and legally attached to certain positions. Totalitarianism is a system of government. The leader has power without being restricted. Moreover, the leader is responsible for the monopolization of all human activities like artistic manifestations, political and communication systems. In democracy personalization exists. The personalization hypothesis states the individual has become more prominent at the expense of parties and collective identities. The question is: Are charismatic authority in totalitarianism and personalization in democracy identical?

\section{Nota O AUTORZE}

Łukasz Scheffs [lukasz.scheffs@amu.edu.pl] - doktorant na Wydziale Nauk Politycznych i Dziennikarstwa UAM w Pracowni Marketingu Politycznego. Jego zainteresowania koncentrują się wokół tematyki szeroko pojętego marketingu politycznego, demokracji i integracji europejskiej. W kręgu jego zainteresowania znajduje się również kwestia personalizacji polskiej sceny politycznej w kontekście zachowań politycznych i społecznych wyborców. 